\title{
Anticonvulsant Activity of Majoon Najah against PTZ Induced Seizure in Swiss Albino Mice
}

\author{
Zeba Afrin ${ }^{1}$, Aisha Siddiqui ${ }^{*}{ }^{2}$, M.A Jafri ${ }^{3}$, Divya vohora ${ }^{4}$, M Asif ${ }^{2}$ \\ ${ }^{1}$ Central Council for Research in Unani Medicine Headquarters, Janakpuri, New Delhi, India \\ ${ }^{2}$ Department of Ilmul Advia, School of Unani Medical Education \& Research, Jamia Hamdard, New Delhi, India \\ ${ }^{3}$ Department of Ilmul Advia, School of Unani Medical Education \& Research, Jamia Hamdard, New Delhi, India \\ ${ }^{4}$ Department of Pharmacology, School of Pharmaceutical Education and Research, Jamia Hamdard, New Delhi \\ *Corresponding author: ashijamal2003@gmail.com
}

Available online at: www.isroset.org

Received: 30/Oct/2018, Accepted: 25/Nov/2018, Online: 31/Dec/2018

Abstract- Objective: To compare the anticonvulsant activity of Majoon Najah, its hydroalcoholc extract and granular form through Pentylenetetrazole (PTZ) test in swiss albino mice.

Material and Methods: Majoon Najah (MN), its hydroalcoholic extract (HEMN) and granular form (GMN) were tested for anticonvulsant activity using Pentylenetetrazole (PTZ) test animal model. To evaluate the effect of test drugs on motor coordination, muscle co-ordination test by rotarod was carried out.

Results: It was found that MN ( $<<0.01)$, HEMN and GMN ( $p<0.001)$ significantly increased the latency of myoclonic jerks and clonic generalized seizures when compared with control. The findings of the rotarod test suggest that the test drugs (MN, HEMN and GMN) did not produced any motor inco-ordination. So MN, HEMN and GMN are safer than conventional antiepileptic drugs.

Conclusion: It can be concluded from the experiment performed that Majoon Najah, its hydoalcoholic extract and granular form possess significant anticonvulsant activity.

Keywords: Majoon Najah, anticonvulsant, pentylenetetrazole, mice

\section{INTRODUCTION}

According to a recent report published by the World Health Organization "Neurological disorders, public health challenges" it is stated that about one billion people worldwide suffer from neurological disorders which are found among all age groups and that 6.8 million people die annually from these disorders. The spectrum of neurological disorders includes epilepsy, stroke, headache, Alzheimer's disease, dementia, parkinson's disease etc [1]. Epilepsy is the world's most common serious disorder of the brain according to World Health Organization [2]. It is approximated that there are 55,00,000 persons with epilepsy in India, 20,00,000 in USA and 3,00,000 in UK. It is estimated that around 50 million people in the world have epilepsy and 5\% of the general population approximately experience at least one seizure at some time in their lives excluding febrile seizures [3].

Epilepsy is a chronic disorder in which the recurrence of seizures is the indispensable feature that is typically unprovoked and usually unpredictable. An epileptic seizure is the outcome of a temporary physiologic dysfunction of the brain caused by a self-limited, abnormal, hypersynchronous electrical discharge of cortical neurons. A seizure is a transient epileptic event, a symptom of disturbed brain function. There are many different types of seizures, each with characteristic behavioural changes and electrophysiologic disturbances that can usually be detected in scalp electroencephalographic (EEG) recordings [4]. According to Unani classical literature, epilepsy (Sara) is the cessation of all sensory faculties of a person and the person suddenly falls on the ground with involuntary movement (Tashannuj) of face and both upper and lower limbs accompanied with a frothy salivary discharge from mouth [5].

Currently available antiepileptic drugs have limited efficacy and their major side effects limit their use and cause difficulties in patient management. These drugs have no effect on epileptogenesis, which is a process that converts the normal 
circuitry of the brain into a hyperexcitable state and provide only symptomatic relief as these drugs suppress seizures. Moreover due to adverse effects, withdrawal symptoms, interactions with other drugs and economic burden antiepileptic drugs (AEDs) could not be used for long term. For example the main limitation of Phenobarbital is its tendency to alter cognition, mood and behaviour. AEDs prescribed to pregnant women may cause fetal anomalies including cognitive impairment, neural tube defects, congenital heart defects. A serious barrier to successful treatment in patients with epilepsy is noncompliance. The major reasons are inconvenient doses, complicated regimens and side effects. Despite massive funding for new AED development, the drugs lack safety and efficacy and about $30 \%$ of patients are still pharmacoresistant [6].

It is reported in a survey by WHO that $80 \%$ of the world population reckon on medicines of plant origin for their primary healthcare [7]. It has been approximated that in developed countries such as United States, plant drugs constitute 25\% of the total drugs, whereas the contribution is as much as $80 \%$ in fast developing countries such as China and India. Hence, the economic importance of medicinal plants is much more to countries such as India than to rest of the world. Antiepileptic drugs with a better efficacy and safety are rarely available which reveal an immense need for developing newer effective and safe alternative antiepileptic compounds. Development of herbal anticonvulsant drugs as an alternative to synthetic drugs will be a precious contribution to health care system [8]. Extensive literature survey reveals that Majoon Najah is an age old, time tested polyherbal preparation of Unani system of medicine which is commonly used for the treatment of epilepsy (Sara) and other neurological disorders. In classical Unani literature it has been described to be useful in Sara (Epilepsy), Malikholia (Melancholia), Ikhtenaqur raham (Hysteria), Insanity etc [9,10,11]; but no scientific study has been conducted in this aspect of Majoon Najah to validate its anticonvulsant activity. In present context there is a need to evaluate this formulation on scientific parameters to validate its efficacy, so that it can be utilized in future for the treatment of convulsive disorders. Hence, it was selected for the present study to evaluate its anticonvulsant activity.

\section{MATERIAL AND METHODS}

All the test formulations (Majoon Najah, Granules and Hydroalcoholic Extract of ingredients of Majoon Najah) were prepared in the Dept. Of Ilmul Advia, School of Unani Medicine, Jamia Hamdard. Before starting the animal experiment, the research protocol was submitted to the IAEC, Jamia Hamdard, New Delhi for ethical approval. The protocol was approved vide Reg. No. 173/GO/Re/S/2000/CPCSEA.

All the required ingredients of Majoon Najah were procured from the raw drug dealers in Khari Baoli market, Old Delhi under the supervision of Guide. All the raw drugs were identified and authenticated by the expert from Dept. of Botany, School of Chemical \& Life Sciences, Jamia Hamdard, New Delhi.

\section{Preparation of Majoon Najah:}

Majoon Najah was prepared as per the procedure mentioned in the pharmacopeia 'National Formulary of Unani Medicine (NFUM) Part II, Vol. I. The ingredients of Majoon Najah are as follows:

Table 1: Ingredients of Majoon Najah [10]

\begin{tabular}{|l|l|l|l|l|}
\hline S. No. & Unani Name & Botanical Name & Parts Used & Quantity \\
\hline 1. & Post-e-halela kabli & Terminalia chebula Retz & Fruit & $40 \mathrm{~g}$ \\
\hline 2. & Post-e-Balela & Terminalia bellerica Roxb & Fruit & $40 \mathrm{~g}$ \\
\hline 3. & Aamla & Emblica officinalis Gaertn. & Fruit & $40 \mathrm{~g}$ \\
\hline 4. & Halela Siyah & Terminalia chebula Retz & Fruit & $40 \mathrm{~g}$ \\
\hline 5. & Turbud & Operculina turpethum Linn & Root & $40 \mathrm{~g}$ \\
\hline 6. & Bisfayej & Polypodium vulgare Linn & Root & $20 \mathrm{~g}$ \\
\hline 7. & Aftimoon & Cuscuta reflexa Roxb. & Whole plant & $20 \mathrm{~g}$ \\
\hline 8. & Ustukhuddus & Lavandula stoechas Mill. & Flowers & $20 \mathrm{~g}$ \\
\hline 9. & Qand safaid (Sugar) & & & $750 \mathrm{~g}$ \\
\hline
\end{tabular}

$\mathrm{MN}$ is prepared as per the procedures, mentioned in the pharmacopeia Part II, Vol. I of National Formulary of Unani Medicine (NFUM).

\section{Powdering the ingredients}

As per the classical method, Halailajat 'Three Myrobalan fruits' (from S.No. 1 to 4) are first dried to evaporate their 
moisture content and pounded in an iron mortar. Initially gentle pounding is employed to break the drugs into small pieces then vigorous pounding is done till they are ground into coarse powder. The powder is then passed through appropriate mesh sieve [12]. The remaining ingredients (from S.No.5 to 8) are dried, powdered and sieved separately.

2. Rubbing (Tad'heen or Charb) the Tirphala with almond oil or sesame oil or Ghee:

Tad'heen or Charb is the process of correction or detoxification in which dry drug is made oily or rubbed with some special oil. This terminology of pharmaceutics is often used for Tirphala. The powdered Tirphala (Separately or with other ingredients of Majoon are rubbed with one of the following oils:

Raughan Badam (Almond oil) [13]

Raughan Zard (Cow Ghee) [13,14]

Raughan Bed Injeer (Castor oil) [15]

3. Mixing the rubbed powder in the Qiwam:

For making Majoon or any of its allied preparations, Qiwam (Base) of different consistencies is generally made, depending on the nature of ingredient drugs to be used in a particular formula. The ingredient drugs in a Qiwam may be used either in powder or liquid form.

The Qiwam is generally made by adding Aab (water), Arq (Distillate) or Aab e Samar (Fruit Juice) etc., in any of the bases of purified Honey with Sugar, Candy or Jaggery etc., and boiled over a low fire till it acquires a required consistency. The bases are generally purified by adding Aab e Leemu (Lemon juice), Satt e Leemu (Lemon extract) or Shibb e Yamani (Alum) etc. Afterwards, the ingredient drugs are mixed in it, to prepare Jawarish, Majoon, Itrifal, Halwa. For making Majoon or any of its preparations the consistency of Qiwam of Majoon is Three Tar (consistency) [13]

Total $250 \mathrm{~g}$ of powder was prepared from ingredients of $\mathrm{MN}$ and weight of sugar was three times of total weight of ingredients i.e. $750 \mathrm{~g}$. Sugar $(750 \mathrm{~g})$ was taken in a container and $225 \mathrm{ml}$ of water was added to it. Then $2-3 \mathrm{~g}$ of benzoic acid and citric acid was added to it as a preservative. Then it was heated on heating mantle on low flame with continuous stirring until boiling was started. Just after the initiation of boiling, container was removed from the flame and then all the powdered ingredients were added and mixed in the prepared Qiwam to prepare MN. Then it was stored in an airtight chamber.

\section{Preparation of Hydroalcoholic extract of MN (HEMN):}

All the crude ingredients of $\mathrm{MN}$ were kept in a drying oven at $40^{\circ} \mathrm{C}$ for about $30 \mathrm{~min}$ to evaporate moisture and powdered in an electrical grinder. The powder obtained was rubbed with Raughan-e-Badam and then extracted in soxhlet's extractor with hydroalcoholic solvent (ethanol and distilled water in ratio 80:20) for about 6 hours at the fixed temperature of $80^{\circ} \mathrm{C}$. The liquid extract cooled and filtered by Whatmann filter paper No.40. Then the filtrate was concentrated over steam bath till it dried completely. The resultant residue was collected and stored for further use. The yield percentage was $44 \%$.

\section{Preparation of sugar free granules (GMN):}

Granules were prepared using wet granulation technique. The powdered ingredients were size reduced and passed through mesh sieve No.80. Then, all the powdered drugs were rubbed (charb) with Raughan-e-Badam. After that, binders like sodium Carboxymethyl Cellulose (Na-CMC) and Hydroxypropyl Methyl Cellulose (HPMC) were mixed with powder using a little amount of distilled water and a doughy mass was formed. The dough was passed through sieve No. 10 and superimposed on sieve No. 44, were dried in an oven and taken as the selected formulation and for further experiment [16].

\section{Comparative study for anticonvulsant activity}

To compare the activity of MN, HEMN and GMN, anticonvulsant activity was evaluated in mice through Pentylenetetrazole (PTZ) Test. Muscle Inco-ordination Test by Rotarod was also carried out.

\section{Experimental animal:}

The study was carried out in Swiss albino mice of either sex weighing 20-25 gm, 2-3 months old. The animals were procured from Central Animal House Facility, Jamia Hamdard, New Delhi.

The animals were given a period of one week prior to the experiment to adjust the standard laboratory conditions. They were maintained under standard laboratory conditions all through the experimental period and were provided with standard rodent diet and water ad libitum. They were housed in clean polypropylene cages at room temperature/ humidity $25 \pm 2{ }^{\circ} \mathrm{C} / 45$ $55 \%$. The animal care procedures and experimental protocol were in according to the guidelines of CPCSEA. The overnight fasted (water ad libitum) animals were transferred to the laboratory one hour prior to the beginning of the experiment. 


\section{Dosage of test drugs [17]:}

The dose of test drugs for mice was calculated by multiplying the human dose with conversion factor of 12 by method of Freireich et al. The human therapeutic dose of $\mathrm{MN}$ is 5-10g as mentioned in the classical Unani literature [10]. The higher dose of MN was given to the mice in present study. The dose of MN for Swiss albino mice was calculated by factor twelve and found to be $1700 \mathrm{~m} / \mathrm{kg}$. Since the hydroalcoholic extract of the test drug was used so the dose of extract was calculated on the yield percentage of extract with reference to the dose of crude drug which was found to be $44.22 \%$. So the dose of extract was found to be $265 \mathrm{mg} / \mathrm{kg}$ which was rounded off as $260 \mathrm{mg} / \mathrm{kg}$. The dose of sugar free granules of MN was calculated as $600 \mathrm{mg} / \mathrm{kg}$ by subtracting the weight of sugar from original formula.

\section{Other drugs:}

Distilled water and sodium valproate (standard drug) were given orally in the dose of $10 \mathrm{ml} / \mathrm{kg}, 300 \mathrm{mg} / \mathrm{kg}$ body weight respectively.

All the test drugs (MN, HEMN, GMN) and standard drug were diluted with distilled water to the desired concentration for dose administration to the mice. All the drugs were administered once orally via gauge needle in volume of $1.5-2 \mathrm{ml}$.

\section{Methodology for screening anticonvulsant activity:}

Comparative screening of test drugs (MN, HEMN, GMN) for anticonvulsant activity was done using Pentylenetetrazole (PTZ) test.

\section{Pentylenetetrazole (PTZ) Test:}

This test was carried out by the method described by Vohora et al. Male swiss albino mice were taken. The mice were divided into five groups of 6 mice each. The mice of first group were given distilled water in a dose of $10 \mathrm{ml} / \mathrm{kg}$ (control group) for 7 consecutive days; Group II were given Sodium valproate (standard drug) in a dose of $300 \mathrm{mg} / \mathrm{kg}$, while Group III, IV and V were given test drugs i.e $1700 \mathrm{mg} / \mathrm{kg}$ of $\mathrm{MN}, 260 \mathrm{mg} / \mathrm{kg}$ of hydroalcoholic extract and $600 \mathrm{mg} / \mathrm{kg}$ of prepared granules orally. Sodium valproate was used as standard drug. Test drugs and standard drug were administered for 7 consecutive days orally.

\begin{tabular}{|l|l|l|l|l|l|}
\hline S.No. & GROUP & AGENT & ROUTE & DOSAGE & DURATION \\
\hline I & Control & Distilled water & Oral & $10 \mathrm{ml} / \mathrm{kg}$ & 7 days \\
\hline II & Standard & Sodium valproate & Oral & $300 \mathrm{mg} / \mathrm{kg}$ & 7 days \\
\hline III & Test Group A & MN & Oral & $1700 \mathrm{mg} / \mathrm{kg}$ & 7 days \\
\hline IV & Test Group B & HEMN & Oral & $260 \mathrm{mg} / \mathrm{kg}$ & 7 days \\
\hline V & Test Group C & GMN & Oral & $600 \mathrm{mg} / \mathrm{kg}$ & 7 days \\
\hline
\end{tabular}

MN= Majoon Najah, HAE= Hydroalcoholic Extract, GMN= Granules of Majoon Najah

On $7^{\text {th }}$ day they all (Group I, II, III, IV \& V) were treated with PTZ $(60 \mathrm{mg} / \mathrm{kg}$ b.w, i.p) $1 \mathrm{~h}$ after drug administration to induce convulsions. The occurrence and latency to myoclonic jerks and clonic-tonic convulsion was noted over a thirty min. period $[18,19]$.

\section{Muscle Co-ordination Test by Rotarod:}

Male swiss albino mice were taken. The mice were divided into three groups of 6 mice each. The mice of group I, II and III were given test drugs i.e. $1700 \mathrm{mg} / \mathrm{kg}$ of $\mathrm{MN}, 260 \mathrm{mg} / \mathrm{kg}$ of hydroalcoholic extract and $600 \mathrm{mg} / \mathrm{kg}$ of prepared granules orally for 7 consecutive days.

Preselected mice (animals that stayed for at least $3 \mathrm{~min}$ on the rotating bar, $24 \mathrm{~h}$ before testing) were placed on the horizontal rotating bar (diameter $2.5 \mathrm{~cm}, 16 \mathrm{rpm}$ ) of the rotarod apparatus, $1 \mathrm{~h}$ after the treatments on $7^{\text {th }}$ day. Total time spent on the rotating bar during a $2 \mathrm{~min}$ session was registered using a stopwatch and the number of fall during the session was also recorded [20]. 


\begin{tabular}{|l|l|l|l|l|l|}
\hline S.No. & GROUP & AGENT & ROUTE & DOSAGE & DURATION \\
\hline I & Test Group A & MN & Orally & $1700 \mathrm{mg} / \mathrm{kg}$ & 7 days \\
\hline II & Test Group B & HAE & Orally & $260 \mathrm{mg} / \mathrm{kg}$ & 7 days \\
\hline III & Test Group C & GMN & Orally & $600 \mathrm{mg} / \mathrm{kg}$ & 7 days \\
\hline
\end{tabular}

MN= Majoon Najah, HAE= Hydroalcoholic Extract, GMN= Granules of Majoon Najah

\section{Statistical analysis}

All the values are expressed as Mean \pm SEM (Standard error of mean). The statistical significance was determined by One way ANOVA followed by Dunett's t Test. Values $\mathrm{p}<0.05, \mathrm{p}<0.01$ were considered as significant and $\mathrm{p}<0.001$ as highly significant.

\section{RESULTS}

Table 2: Effect of MN, HEMN and GMN in PTZ induced convulsions

\begin{tabular}{|c|c|c|c|c|c|}
\hline S. No. & Groups & $\begin{array}{l}\text { Dose }(\mathrm{mg} / \mathrm{kg} \text {, } \\
\text { p.o.) }\end{array}$ & $\begin{array}{l}\text { Latency to } \\
\text { myoclonic jerks (s) }\end{array}$ & $\begin{array}{l}\text { Latency to clonic } \\
\text { generalized seizures }(s)\end{array}$ & $\begin{array}{l}\text { Duration of } \\
\text { clonic } \\
\text { generalized } \\
\text { seizures(s) }\end{array}$ \\
\hline 1 & $\begin{array}{l}\text { DW } \\
\text { (Plain control) }\end{array}$ & $10 \mathrm{ml} / \mathrm{kg}$ & $62.87 \pm 5.27$ & $201.86 \pm 12.89$ & $18.5 \pm 1.18$ \\
\hline 2 & $\begin{array}{l}\text { SVP } \\
\text { (Standard control) }\end{array}$ & $300 \mathrm{mg} / \mathrm{kg}$ & $289.65 \pm 22.16^{* * *}$ & $1529.67 \pm 143.05 * * *$ & $6.50 \pm 2.50 * * *$ \\
\hline 3 & $\begin{array}{l}\text { MN } \\
\text { (Test group A) }\end{array}$ & $1700 \mathrm{mg} / \mathrm{kg}$ & $152.50 \pm 12.89 * *$ & $890.23 \pm 46.90^{* *}$ & $11.2 \pm 1.18^{* *}$ \\
\hline 4 & $\begin{array}{l}\text { HEMN } \\
\text { (Test group B) }\end{array}$ & $260 \mathrm{mg} / \mathrm{kg}$ & $202.69 \pm 15.20^{* * *}$ & $1296.37 \pm 196.87 * * *$ & $10.5 \pm 1.38 * *$ \\
\hline 5 & $\begin{array}{l}\text { GMN } \\
\text { (Test group C) }\end{array}$ & $600 \mathrm{mg} / \mathrm{kg}$ & $189.60 \pm 20.78^{* * *}$ & $1119.98 \pm 172.23 * * *$ & $9.83 \pm 0.95 * *$ \\
\hline
\end{tabular}

Each value is represented as Mean \pm SEM, No. of animals $(\mathrm{n})=6$, DW=standard $(\mathrm{PHT})=$ Phenytoin, MN= Majoon Najah, HEMN=Hydroalcoholic extract of ingredients of Majoon Najah, GMN=Granules of Majoon Najah. Treatment duration=7 days.

One way ANOVA followed by Dunett's t Test.

$* \mathrm{p}<0.05, * * \mathrm{p}<0.01, * * * \mathrm{p}<0.001$ vs Group I (Plain control)

\section{Figure 1}


Effect of MN, HEMN and GMN on latency of myoclonic jerks during PTZ test

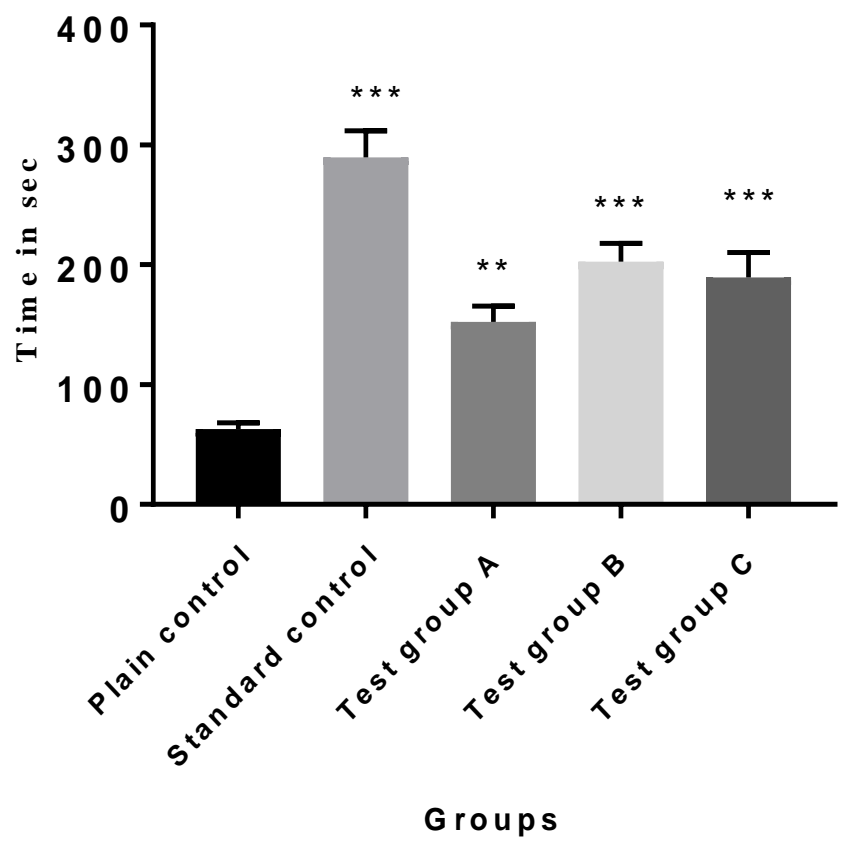

Figure 2

Effect of MN, HEMN and GMN on latency of clonic generalized seizuresduring PTZ test

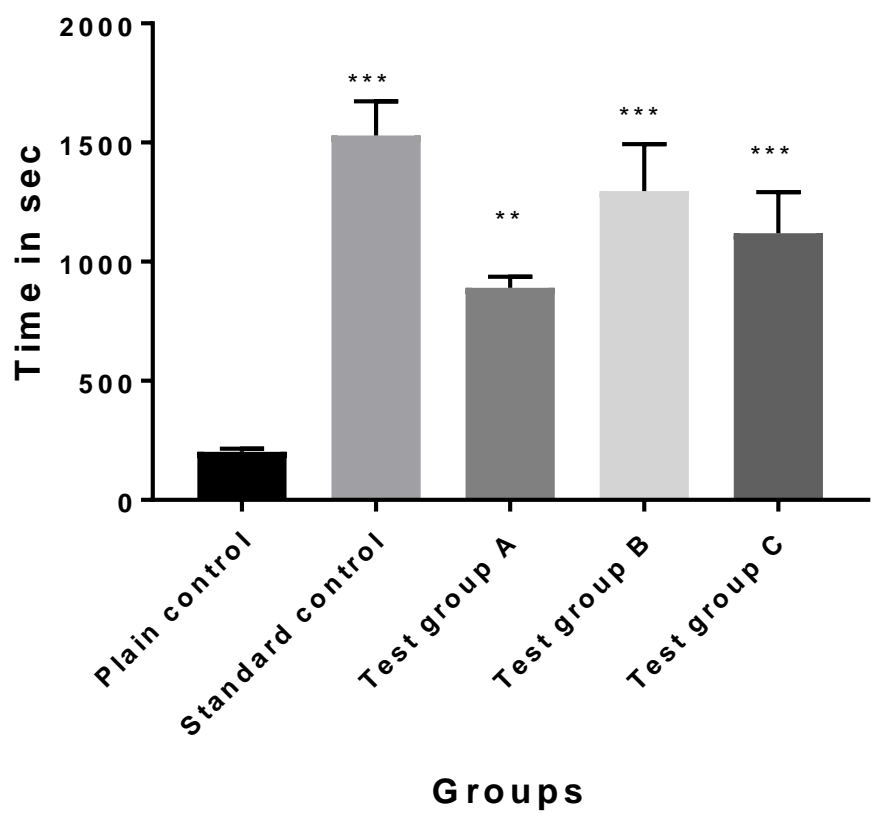

Figure 3 
Effect of MN, HEMN and GM on duration of clonic generalized seizureduring PTZ test

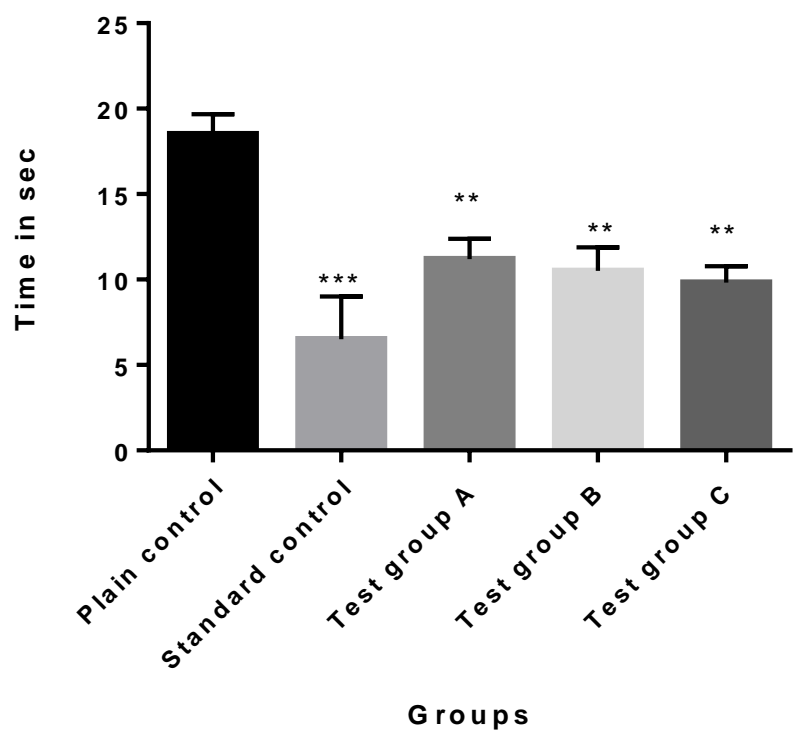

- Effect of MN, HEMN and GMN on muscle coordination test by Rotarod:

The test drugs (MN, HEMN and GMN) did not produced any inco-ordination as the animals overstayed on the revolving rod beyond 3min, much similar to the control animals.

Table 3: Effect of MN, HEMN and GMN on duration of stay on revolving rod of rotarod apparatus

\begin{tabular}{|l|l|l|l|}
\hline S.No. & Groups & Dose $(\mathbf{m g} / \mathbf{k g}, \mathbf{p . o .})$ & Duration of stay on revolving rod (after training) \\
\hline 1 & $\begin{array}{l}\text { Distilled water } \\
\text { (Plain control) }\end{array}$ & $10 \mathrm{ml} / \mathrm{kg}$ & $248.9 \pm 0.75$ \\
\hline 2 & $\begin{array}{l}\text { MN } \\
\text { (Test group A) }\end{array}$ & $1700 \mathrm{mg} / \mathrm{kg}$ & $247.8 \pm 0.18$ \\
\hline 3 & $\begin{array}{l}\text { HEMN } \\
\text { (Test group B) }\end{array}$ & $260 \mathrm{mg} / \mathrm{kg}$ & $247.7 \pm 0.14$ \\
\hline 4 & $\begin{array}{l}\text { GMN } \\
\text { (Test group C) }\end{array}$ & $600 \mathrm{mg} / \mathrm{kg}$ & $248.4 \pm 0.48$ \\
\hline
\end{tabular}

Each value is represented as Mean + SEM, No. of animals $(n)=6, D W=$ standard $(P H T)=P h e n y t o i n, M N=$ Majoon Najah, HEMN=Hydroalcoholic extract of ingredients of Majoon Najah, GMN=Granules of Majoon Najah. Treatment duration=7 days.

One way ANOVA followed by Dunett's t Test

No statistical significant difference (p>0.05)- Test group A, B \& C vs Group I (Plain control)

Figure 4 
Effect of MN, HEMN and GMN onduration of stay on revolving rod during Rotarod test

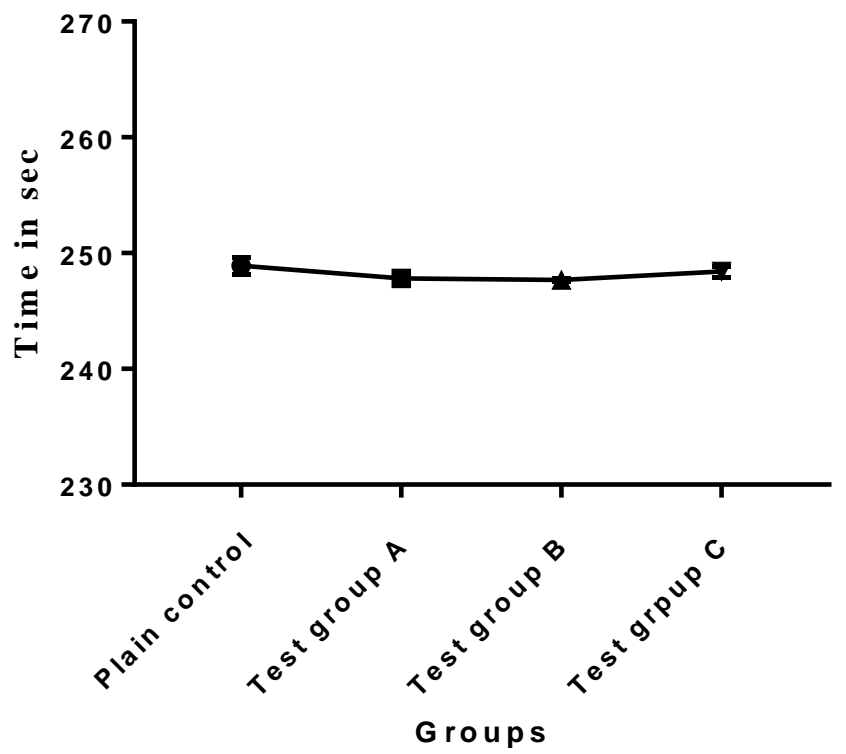

\section{DISCUSSION}

Epilepsy is the second most common chronic neurological condition seen by neurologists [3]. Antiepileptic drugs with a better efficacy and safety are rarely available which reveal an immense need for developing newer effective and safe alternative antiepileptic compounds.

Majoon Najah (MN) is one of the important Unani semisolid formulations which is traditionally used for the treatment of various neurological disorders like epilepsy, hysteria, melancholia, insanity, schizophrenia etc. It is composed of 8 ingredients viz. Halaila siyah (Terminalia chebula), Halalila kabli (Terminalia chebula), Balela (Terminalia bellirica), Amla (Emblica officinalis), Turbud (Operculina turpethum), Aftimoon (Cuscuta reflexa), Bisfayej (Polypodium vulgare) and Ustukhudoos (Lavandula stoechas).

According to Unani concept, the causative matter responsible for epilepsy is mostly phlegmatic and sometimes black bile is responsible for it [21].

Various scientific studies report that ingredients of Majoon Najah have significant anticonvulsant activity. Experimental studies revealed that Halaila siyah and Halaila kabli (Terminalia chebula) has significant anticonvulsant, neuroprotective, anxiolytic and antioxidant activities [22,23,24,25]. The ethanolic extract of Terminalia chebula was evaluated for anticonvulsant activity. It reduced the duration of seizures produced by maximal electroshock and delayed the latency of seizures produced by pentylenetetrazole and picrotoxin. The study demonstrated that ethanolic extract of Terminalia chebula has anticonvulsant activity [26].

Balela (Terminalia bellirica) has been reported to possess antioxidant and antianxiety properties [27,28]. T. Chebula, T. Bellirica and E.officinalis were evaluated for in vitro antioxidant and reactive oxygen species scavenging activities and the study conclude that $70 \%$ methanol extracts of T.chebula, T.bellirica and E.offficinalis imposes the fact that it might be useful as potent source of natural antioxidant.

It has been reported experimentally that Amla (Emblica officinalis) possess significant anticonvulsant and antioxidant effects. E. officinalis was evaluated for anticonvulsant activity and it was concluded that hydroalcoholic extract of E. officinalis dosedependently increased the latencies of myoclonic jerks and completely abolished generalized tonic seizures produced by PTZ $[29,30]$.

Various studies suggest that Turbud (Operculina turpethum) has antioxidant activity [31]. O.turpethum showed the presence of glycosides, saponins, flavanoids, steroids and carbohydrates. Turpethin is mainly responsible for its purgative action. 
Bisfaij (Polypodium vulgare) is reported experimentally to possess significant anticonvulsant activity [32]. Aftimoon (Cuscuta reflexa) is reported to have significant anticonvulsant, anxiolytic and antioxidant effects [33,34].

A number of experimental studies suggest that Ustukhudoos (Lavandula stoechas) possess significant anticonvulsant and antioxidant activities. L. stoechas was evaluated for anticonvulsant activity and was concluded that it increased the latency and a reduction of level of the severity of convulsions. Complementary test suggested that this activity is related with the blocking of canals of calcium. The inhaling lavender oil vapor blocked pentylenetetrazole- and nicotine-induced convulsion and electroshock convulsion in mice $[35,36]$. It may safely be concluded that MN possess anticonvulsant activity due to the above mentioned actions of ingredients of test formulation (MN).

For comparative screening of anticonvulsant activity of classical Majoon Najah (MN), its prepared hydroalcoholic extract (HEMN) and granular form (GMN), one experimental model was selected i.e. Pentylenetetrazole (PTZ) induced seizures test for swiss albino mice. PTZ induced seizure test is considered as an experimental model for the "generalized absence seizures" and also a valid model for human generalized myoclonic seizures [37].

In Pentylenetetrazole (PTZ) induced seizure test parameters like latency of myoclonic jerks, latency of clonic generalized seizures, duration of clonic generalized seizure and percent protection were observed. It was found that MN ( $<<0.01$ ), HEMN and GMN $(p<0.001)$ significantly increased the latency of myoclonic jerks and clonic generalized seizures when compared with control. The observations showed that MN, HEMN and GMN have strong anticonvulsant effect although MN, HEMN and GMN decreased the duration of clonic generalized seizures less significantly $(\mathrm{p}<0.01)$ in comparison to standard drug sodium valproate. Sodium valproate (standard) have extremely significant effect $(\mathrm{p}<0.001)$ on duration of clonic generalized seizure. HEMN showed more significant results than MN and GMN although intra-comparison showed that the difference is not statistically significant.

It was found that treatment with test drugs (MN, HEMN \& GMN) on PTZ induced mice significantly delayed the latency of myoclonic jerks and clonic generalized seizures. The main action of the pentylenetetrazole-induced seizure is reducing $\mathrm{g}$ aminobutyric acid (GABA) level in the cortex. GABA has been reported as the principal inhibitory neurotransmitter in the central nervous system of mammals and has been implicated in convulsions as it mediates the inhibition of neuronal responsiveness and activity by increasing the chloride-ion conductance through the opening of the chloride ion channel [38]. The findings of the present study tend to suggest that test drugs (MN, HEMN \& GMN) might have delayed the occurrence of pentylenetetrazole-induced seizure by acting on GABAergic system.

Anticonvulsant activity of the MN may also be attributed to the cumulative anticonvulsant effect of all of the ingredients of MN.

It is reported that most of the antiepileptic drugs cause ataxia and adverse effects on cognition and behaviour. So it is important to screen the effect of any anticonvulsant drug on muscle co-ordination. To evaluate the effect of drug on motor co-ordination, muscle co-ordination test by rotarod was carried out. In muscle co-ordination test by rotarod, time spent on revolving rod of rotarod apparatus was observed. Mice of treated groups (MN, HEMN \& GMN) overstayed on the revolving rod beyond $3 \mathrm{~min}$ much similar to the mice of control group. There was no statistical significant difference $(p>0.05)$ between mice of treated group and control group. The findings of this test suggest that the test drugs (MN, HEMN and GMN) did not produced any motor inco-ordination. So MN, HEMN and GMN is safer than conventional antiepileptic drugs.

It can be concluded that the administration of MN, HEMN \& GMN show promising anticonvulsant activity in ICES test and intra-comparison of these test drugs (MN, HEMN \& GMN) did not produced any statistical significant difference ( $>0.05)$ in activity. So the study confirms that the hydroalcoholic extract of ingredients of Majoon Najah and its sugar free granules have anticonvulsant activity like the conventional form of Majoon Najah and there is no statistical significant difference in its effect.

The conventional form Majoon Najah, its hydroalcoholic extract and sugar free granules, all these forms did not produce any motor inco-ordination as none of the animals treated with test drugs fell off before $3 \mathrm{~min}$. Further studies are needed to evaluate exact chemical ingredient and mechanism of action of potential anticonvulsant effect of Majoon Najah.

\section{REFERENCES}

[1]. T. A Dua, "Neurological Disorders: public health challenges", World Health Organization, Geneva, 2006.

[2]. Anonymous, "Executive Summary. In Atlas: Epilepsy Care in the world", World Health Organization, Geneva, pp.3, 2005.

[3]. R. Sridharan, "Epidemiology of Epilepsy”, Current Science, Vol. 82, Issue 6, pp.664-670, 2002.

[4]. H.H. Merritt \& L.P. Rowland, “Merritt's Neurology (10th Edition)”, Lippincott Williams \& Wilkins Publishers, 2000. 
[5]. M.K. Azam, “Al-Akseer (Urdu Translation by Kabeeruddin HM)”, Aijaz Publishing House, New Delhi, pp.151-164, 2010.

[6]. A. Wahab, "Difficulties in Treatment and Management of Epilepsy and Challenges in New Drug Development", Pharmaceuticals, Vol. 3, pp.2090-2110, 2010.

[7]. V. Kamboj, “Herbal medicine”, Current Science, Vol. 78, Issue 3, pp. 35-39, 2000.

[8]. R.K. Malvi, B. Papiya, S. Sunny \& S. Jain, "Medicinal plants used in the treatment of epilepsy", International Research Journal of Pharmacy, Vol. 2, Issue 2, pp.32-39, 2011.

[9]. J.A. Hassan, “Zakheera Khwarzam Shahi”, Vol. II, pp.196-198, YNM.

[10]. Anonymous, "National Formulary of Unani Medicine”, Part I, Ministry of Health \& Family Welfare (Department of AYUSH), Govt. of India, New Delhi, pp.138, 2006.

[11]. Anonymous, "The Useful plants of India”, Publications \& Information Directorate, CSIR, New Delhi, pp.152,319,320,409, 1986.

[12]. S.S. Chaudhary, "Solid dosage forms in unani ssytem of medicine", Journal of Pharmaceutical and Scientific Innovation, Vol. 2, Issue. 3, pp.17-22, 2013.

[13]. Anonymous, "NFUM, Part II, Vol. I”, CCRUM, Ministry of Health \& Family Welfare, New Delhi, pp. 100,192, 2007.

[14]. D. Z. Antaki, “Tadhkiratu Ulil Albaab Wal Jame Lil Ajabil Ujaab”, Part I, Al-Matba Atul Aamiratus Saqafiyah, Misr, 1899.

[15]. G.M. Choghtai \& F. Choghtai, "Bayaz-e-Ferozi”, Sheikh Muhammad Basheer \& Sons, Lahore, pp.163, YNM.

[16]. A. R. Gennaro, "Remington: The Science and Practice of Pharmacy”, Vol. I (20th Edition), Lippincott Williams \& Wilkins, pp. 36, YNM.

[17]. Anonymous, "Guidance for industry estimating the maximum safe starting dose in initial clinical trials for therpaeutics in adult healthy volunteers", Department of Health and Human Services, Food and Drug Administration, Center for Drug Evaluation and Research, U.S., pp. 6-7, 2005.

[18]. D. Vohora, S. Pal \& K. Pillai, "Thioperamide, A selective Histamine H3 receptor antagonist, protects against PTZ-induced seizures in mice”, Pharmacology letters, Life Sciences, Vol.66, Issue.22, pp. 297-301, 2000.

[19]. R. Joshi, K. Reeta, S. Sharma, M. Tripathi \& Y. Gupta, "Panchagavya Ghrita, an Ayurvedic formulation attenuates seizures, cognitive impairement and oxidative stress in pentylenetetrazole induced seizure in rats”, Indian Journal of Experimental Biology, Vol.53, pp. 446$451,2015$.

[20]. G. Radha \& A. Goel, "Effect of Nebivolol on Anticonvulsant Property of Sodium Valproate along with Neuropharmacological benefits in Rodents Models of Epilepsy and Behaviour in Mice", Journal of Clinical and Experimental Neuroscience, Vol.1, Issue.1, 2013.

[21]. A. M. Z Razi, "Kitabul Havi (Urdu Translation by CCRUM)”, Vol. I, Ministry of Health \& Family Welfare, New Delhi, pp. 106-130,1997.

[22]. H.-Y. Cheng, T.-C. Lin, K.-H. Yu, C.-M. Yang, \& C.-C Lin, "Antioxidant and Free Radical Scavenging Activities of Terminalia chebula”, Biol. Pharm. Bull, Vol. 26, Issue.9, pp. 1331-1335, 2003.

[23]. Senthil G. K, \& Subramanian S. Evaluation of Antioxidant Potential of Terminalia chebula fruits studied in Streptozotocin-Induced Diabetic Rats. Pharmaceutical Biology. 2007; 45(6): 511-518.

[24]. Shekhar C. R., Manohar V., \& Rao S. Antidepressant activity of aqueous extracts of fruits of Terminalia chebula in rats. International Journal of Pharmacy and Pharmaceutical Sciences. 2012; 4(4): 449-451.

[25]. C. L Chang \& C. S. Lin, "Phytochemical Composition, Antioxidant Activity and Neuroprotective Effect of Terminalia chebula Retz Extracts", Evidence-Based Complementary and Alternative Medicine, pp. 1-7, 2012.

[26]. J. Debnath, U. R. Sharma, B. Kumar \& N. S. Chauhan, "Anticonvulsant activity of ethanolic extracts of Terminalia chebula on experimental animals", International Journal of Drug Development \& Research, Vol.2, Issue.4, pp. 764-768, 2010.

[27]. B. Hazra, R. Sarkar, S. Biswas \& N. Mandalnn, "Comparative study of the antioxidant and reactive oxygen species scavenging properties in the extracts of the fruits of T.chebula, T.bellerica and E.officinalis" BMC, Complementary and Alternative Medicine, pp.1-15, 2010.

[28]. S. R. Chandra, V. Manohar, P. Bharathi \& M. Rai, "Attenuation of anxiety on acute administration of aqueous extract of Terminalia belerica fruit pulp in Swiss albino mice” International Journal of Basic \& Clinical Pharmacology, Vol.6, Issue.2, pp. 303-307, 2017.

[29]. M. Golechha, M. Bhatia, A. Jagriti, \& D. Singh, "Hydroalcoholic extract of Emblica officinalis Gaertn. affords protection against PTZ induced seizures, oxidative stress and cognitive impairement in rats”, Indian Journal of experimental Biology, Vol. 48, pp. 474-478, 2010.

[30]. S. Khopde, K. I. Priyadarshani, H. Mohan, V. Gawandi, J. Satav, J. Yakhmi, "Characterizing the antioxidant activity of amla (Phyllanthus emblica) extract”, Current Science, Vol.81, Issue.2, pp. 185-190, 2001.

[31]. C. Anbuselvam, K. Vijayavel \& M. Balsubramaniyan, "Protective effect of Operculina turpethum against 7,12 dimethylbenz(a)anthracene induced oxidative stress with reference to breast cancer in experimental rats", Chemico Biological Interactions, Vol. 168, pp. 229-236, 2007.

[32]. P. A. Dar, G. Sofi \& M. Jafri, “Polypodium vugare Linn. A Versatile Herbal medicine: A Review”, IJPSR, Vol.3, Issue.6, pp. 1616-1620, 2012.

[33]. S. Yadav, V. Tripathi, R. Singh, \& H. Pandey, “Antioxidant activity of Cuscuta reflexa stems”, Indian J. Pharm Sci, Vol. 62, Issue.6, pp. 477-478, 2000.

[34]. S. Thomas, S. Srikumar, C. Velmurugan \& A. B. Kumar, "Evaluation of anxioltic effect of whole plant of "Cuscuta reflexa", World Journal of Pharmacy and Pharmaceutical Sciences, Vol.4, Issue.8, pp. 1245-1253, 2015.

[35]. H. Sebai, S. Selmi, K. Tibi, A. A. Souli, N. Gharbi \& M. Sakly, "Lavender (Lavandula stoechas L.) essential oils attenuate hyperglycemia and protect against oxidative stress in alloxan-induced diabetic rats". Lipids in Health and Disease, pp. 1-9, 2013.

[36]. S. Miraj, "Lavandula stoechas L: A systematic review of medicinal and molecular perspectives”, Der Pharmacia Lettre, Vol.8, Issue.13, pp. 56-58, 2016.

[37]. W. Loshcher \& D. Schmidt, "Which animal models should be used in the search for new antiepileptic drugs? A proposal based on experimental and clinical considerations", Epilepsy Research, Vol.2, pp. 145-181, 1988.

[38]. S. Mehrzadi, A. Shojaii, S. A. Pur \& M. Motevalian, "Anticonvulsant Activity of Hydroalcoholic Extract of Citrullus colocynthis Fruit:Involvement of Benzodiazepine and Opioid Receptors", Journal of Evidence-Based Complementary \& Alternative Medicine, Vol.21, Issue.4, pp. 31-35, 2015. 